\title{
Russia: Culture, Cultural Policy, and the Swinging Pendulum of Politics
}

\author{
Lena Jonson
}

Putin's political agenda after he returned as President in May 2012 reflected a drastic turn towards authoritarian conservatism. The turn was the result of processes going on for most of the 2000s, but as it became official policy in 2012 , it reminded of a pendulum in swing that had reached an extreme position. It was a paradigm shift and a turn of 180 degrees away from Mikhail Gorbachev's and Boris Yeltsin's efforts to reform, democratize and develop Russia. A first question of this paper is how the new conservative agenda was reflected in the cultural sphere, in state cultural policy. A second question is what made the pendulum make the swing that far towards authoritarian conservatism.

The term culture may have two meanings: on the one hand it denotes the values specific for a certain society at a certain time. Culture has been defined as "the linked stock of ideas that define a set of common sense beliefs about what is right, what is natural, what works" (Rochon 1998, 9). In a more narrow sense it may denote the sector of the arts and intellectual thought. A direct link exists between these two meanings as people of the cultural sphere are crucial for society's production of ideas and concepts whether formulated along predominant discourses or posed as alternatives. This function of the intellectuals has historically been the starting point for all discussions regarding their importance for social and political change. ${ }^{1}$

Cultural change takes place in society as the conceptual categories with which reality is defined are altered (Rochon 1998, 15). Such alterations may be the result of campaigns and manipulations from above or they may emanate from below. When social, economic or political realities drastically change, new ways of looking at life and new concepts with which to comprehend reality, are needed. Without concepts to analyze a phenomenon, it is difficult to respond to it. What concepts and categories are used will determine the analysis, and thus also the direction of the response. This is the basis of the dynamics of political contention in society between various political forces. Conten-

1 Compare Antonio Gramski, Prison notebooks.

(C) LENA JONSON, 2019 | DOI:10.1163/9789004366671_003

This is an open access chapter distributed under the terms of the prevailing CC-BY-NC-ND License. 
tion may take place between the predominant discourse and those questioning and challenging it, but also between factions within these flanks.

Several factors explain why and how a paradigm shift takes place. One factor, most often underestimated, is the role played by small intellectual communities in formulating new ideas and system of values that correspond to and capture people's sentiments of fear, hope and demands. By providing "ideological glasses", they also indicate recipes of what has to be done.

The formulation of new ideas occurs initially within relatively small communities of critical thinkers, writes Tomas R. Rochon (1998, 22). These intellectuals do not necessarily belong to a formally constituted organization, but are rather part of a self-aware, mutually interacting group that he calls "critical communities". They are critical of the political establishment and challenge ways of looking and interpreting. Such communities have only an indirect influence, however. They become powerful only when they are picked up by social or political actors, which integrate them into social and political movements, carry their ideas to a wider audience, provoke a re-examination of existing values, and thereby create social and political pressure on the authorities for change. ${ }^{2}$ Their ideas can also be directly picked up by those in power, who appropriate the concepts for their own purposes thereby selecting concepts that are instrumental in legitimatizing policy. This means that what once started as ideas of a counter-establishment community may become the forefront ideas of the ruling regime or of a lobby group close to the regime.

A first part of this paper analyses the drastic turn of Russian state cultural policy after 2012. A second part discusses how this turn came about by focusing on the role of various small intellectual communities for the change of policy.

\section{A Conservative State Cultural Policy in the Making}

Putin had for a long time recognized the problem of formulating a national concept that would unify the nation and legitimate the regime. ${ }^{3}$ In this regard his speech at the Valdai Club in September 2013 did not differ. There he emphasized the importance of identity in the spiritual, cultural and national senses, and seriously called for restoring a cultural code with links to Russian national tradition and history. Answering the questions "Who are we?" (Kto my?) and "Who do we want to become?" (Kem my khotim byt?), he gave the signal for the

2 Rochon writing about democratic societies have mainly this option in mind.

3 Already Boris Yeltsin set up a commission to work out a concept of a "national idea" for Russia. During Putin this task became more urgent. 
working out of a new state policy for the cultural sector (Rossiskaya gazeta 2013). His words turned the political focus directly to culture. Since the Russian Constitution explicitly forbids any state ideology, Putin's call was formulated as a question of identity and as a need for a Russian 'national idea'. His speech was welcomed by conservative groups which regarded it a first step forward in formulating a state ideology (Stepanov 2013). ${ }^{4}$

His first priority when reinstated as president in May 2012 had been to wipe out the protest movement. The police clampdown at the Bolotnaya Square demonstration on the day before his inauguration was followed by waves of arrests of demonstrators, charges of causing 'mass riots' and various forms of harassments against the leaders of protest. These acts seriously coloured the atmosphere in society. Media campaigns forwarded the message that protests were created by foreign secret services and were initiated by the West for the purpose of undermining Russia. ${ }^{5}$ Laws hastily introduced in the Duma during the summer targeted oppositional activities. ${ }^{6}$

Putin's new political agenda made patriotism, religion and moral restoration the political priorities. In October 2012 a special section of the presidential administration dedicated to issues of patriotic education and strengthening spiritual-normative values was set up (Grani 2012). Work started on introducing patriotism as a subject in schools (Grani 2014). ${ }^{7}$ Previous plans to write new history schoolbooks according to a patriotic understanding of history developed further, and in February 2013 he ordered a commission to work out

4 "We hope the Valdai speech becomes the first step in formulating a state ideology without which national unity and a genuine Russian revival are impossible."

5 The films 'Provokatory' I, II and III by Arkadii Mamontov were broadcast on TV1 on 24 April, 11 September and 16 October 2012. 'Anatomiya Protesta' I and II, were made by NTV and broadcast on 15 March and 5 October 2012. See also Mel'nikov (2012).

6 It became illegal to organize, participate in or call for participation in demonstrations for which the authorities had not given permission. The penalties for such activities were substantially increased (Federalnyi zakon RF ot 8 iyunya 2012g, N 65-F3 g, Moskva. [Federal law]). A new law on slander was introduced with a vague definition that would limit the opportunities for journalists and the opposition to criticize public leaders and civil servants (Federalnyi zakon ot 28 iyulya 2012g. No 141-F3)). Foreign financial support for non-commercial nongovernmental organizations was stigmatized and effectively obstructed, since such NG Os had to register as 'foreign agents' ( $\mathrm{RF}$ Federalnyi zakon. $\mathrm{O}$ vnesenii izmenenii $\mathrm{v}$ otdelnye zakonodatelnye akty R $\mathrm{F} v$ chasti regulirovaniya deyatelnosti nekommercheskikh organizatsii, vypolnyayushchikh funktsii inostrannogo agenta (RF Federalnyi zakon ot 2007.2012g. No 121-F3. One Duma delegate who was especially active in initiating new draft laws was Alexander Sidyakin, the author of the drafts of three laws - on meetings, on non-commercial organizations as 'foreign agents' and on responsibility for offending the feelings of believers. Sidyakin has been referred to as a 'Zhirinovsky' of United Russia (New Times, 2012).

7 In late March 2014 special school lectures were introduced to explain the events of the Crimea joining Russia (Grani 2014). 
a concept for a series of school history books "without internal contradictions and ambiguous interpretations" (Lenta 2013). ${ }^{8}$ The Orthodox Church was given a central role in formulating and spreading ethical, moral and religious values. The Church got a foothold in the school system through courses on Orthodox culture in 2012 for the fourth class, and the church later tried to further extend its influence and position in the schools (Grani 2014). A new law aimed at protecting the health and moral of children outlawed text material that could be suspected to be "propaganda for non-traditional sexual orientations" (Russian Government 2013). A draft on protecting the feelings of believers from offence and defilation of religious sanctuaries had by the time it was signed by the president in the summer of 2013 broadened the definition of the crime to include "acts of clear lack of respect to society carried out with the urpose of offending the religious feelings of believers" (Federalnyi zakon 2013). ${ }^{9}$

The new political agenda was branded "conservative" and Putin now directly and strongly positioned his policy upon conservatism (Nezavisimaya gazeta 2013). The new atmosphere in society was immediately felt in the cultural sector, first of all on the art scene, where in 2012 a wave of scandals appeared around exhibitions of contemporary art. The major contraveners were Marat Gelman, one of Russia's most famous gallerists, and representatives of the Orthodox Church, various rightist patriotic-religious organizations such as Narodnyi sobor, and Cossack organizations. The latter called Gelman an active blasphemer and a Russophobe and tried to prevent two exhibitions he had curated ("Rodina" and "Icons") from touring the country (Jonson 2015a).

The distinctly conservative profile of the new Minister of Culture Vladimir Medinskii, appointed in May 2012, was well placed in the new political situation. Known as an historian and the author of a series of books entitled Myths about Russia, his views were well known. One critic, Aleksandr Morozov (2013), characterized them as Russian "Weimar resentment", that is, feelings of national indignation over the lost position of a once great power.

Medinskii immediately tried to make an imprint on policy. In contrast to his predecessors, who had left the cultural sphere to fend for itself, Medinskii wanted to actively intervene in cultural life. He embarked on a reorganization of cultural institutions. Referring to economic efficiency and strict management, he started to merge, reorganize or close institutions and replaced respected directors with young, loyal managers. The result was sometimes that the whole staff resigned, as in the case of the Museum of Cinema. ${ }^{10} \mathrm{He}$ con-

$8 \quad$ Then President Dmitrii Medvedev had initiated such work already in 2009.

9 For a discussion of the implications of the new law see Mel'nikov and Orlova (2013).

10 About this conflict see Nicodemus (2014). 
sciously used the allocation of resources as a carrot or a stick to have institutions follow state policy. Critics clearly saw an effort by Medinskii to redesign cultural life according to the new conservative paradigm.

Medinskii early demonstrated an interest in hands-on decision-making and the film sector became the first field in which he directly intervened. His combination of appointing loyal people, steering the flow of monetary support, and using expert councils was perceived as a model for how he was to gain control over other cultural sectors as well (Borisova 2012). Declaring a priority for patriotic films, he took control of the Film Fund for State Support to Film Production. A first conflict took place over the film Milyi Khans, dorogoi Petr (Dear Hans, Dear Peter) by Aleksander Mindadze. It told about the friendship and competition between a Russian and a German engineer during a sensitive period of Soviet-Russian cooperation in the end of 1930 immediately before the war. The ministry sent the film to a military-historical council whose experts turned it down, arguing that such cooperation in which Hans and Petr participated could hardly have taken place that late before the war. Critics of this decision concluded: "This case...shows that portraying historical events can be done only the way the state remembers them. Otherwise, in the name of the ministry, the state will create as many expert councils as necessary in order to have its way." Mindadze gave in, changed the time period of his film and secured financing from the ministry (Karev and Aleksei Krizhevskii 2013). ${ }^{11}$

The very thought that the ministry would be allowed to intervene in cultural production found little support within the arts community. Many feared a future direct state involvement in which the state commissions, for example, film productions. Naum Kleiman (2014), the former director of the Cinema Museum (Muzei kino), warned against such commissioning. He said, "Not a single ministry, not the wisest minister, not a single civil servant even if he passed three academies, can do what the artists do: catch the movement of hearts, understand the despair and the hopes of society and find the corresponding vivid system, which at least a bit reorganizes, improves, and raises society to a new level."

Contemporary art early became a target of conservative criticism as evident from the verdicts of guilty in the legal processes against the organizers of the art exhibitions Beware! Religion of 2003 (verdict reached in 2005) and Forbidden Art of 2007 (verdict reached in 2010) (Jonson 2015a). Medinskii seemed to especially target contemporary art for its critical edge. He reduced its impor-

11 See also the interview with Medinskii 'Ministr kul'tury RF Vladimir Medinskii (Kul'tura 2013). 
tance by using the term "contemporary" for all living artists. ${ }^{12}$ In the Ministry's report of activities during 2013, priority was given to academic and traditional folk art. ${ }^{13}$ Although the ministry continued to finance a lion part of the Moscow biennale of contemporary art and Medinskii opened it in 2013, his words about the major project of the biennale were given great media attention: "I kept thinking: Why doesn't anyone shout 'the king is naked!?" He asked rhetorically, "Why do we, under the label of contemporary art, have to see something abstract-cubic, clumsy, in the form of a pile of bricks? And, moreover, it is paid for by public money! Not to mention that this is incomprehensible to the absolute majority of the inhabitants of Russia" (Iablokov 2013).

The reaction therefore became strong when in December 2014 Medinskii's deputy, Vladimir Aristarkhov, announced that the ministry planned to sponsor art that has a "positive impact on people" (Lapina 2014). His words seemed a clear indication of where the ministry was heading in relation to contemporary art (Nezavisimaya gazeta 2014). Later that month the ministry's section for fine art that had focussed on contemporary art, merged with the section for folk art in the Ministry of Culture. The art community regarded this a sign of the ministry's negative attitude towards contemporary art and of a change in state cultural policy. ${ }^{14}$

In spring 2014 a draft for guidelines for a new state cultural policy were published and in December that year signed as a presidential decree "Foundations for a New State Cultural Policy" (Russian Government 2014). The draft was worked out by a group in the presidential administration (under the head of the presidential administration Sergei Ivanov and Vladimir Tolstoi, presidential adviser and director of the Yasnaya Polyana Museum), was published in May in Rossiiskaya gazeta (2014). It was a cleaned up and modified version of a working paper by the Ministry of Culture published in April by Izvestiya (2014), which had met strong reaction..$^{15}$ In spite of the more neutral wording and formulations of both the May document and the final one of the presidential decree, the major thoughts of the working paper remained. In order to understand

12 See the formulation from the ministry's report (2013a, 132): "A promising direction of the development of contemporary art in Russia is the traditional folk culture".

13 See the criticism in 'Minkult otorvalsya ot zhizni', Nezavisimaya gazeta September 18, 2014. For the report see Ministerstvo kul'tury Rossiiskoi Federatsii (2013a, 120-133). See the criticism by Leonid Bazhanov of the NCCA in "Minkul'tury likvidirovalo otdel, otvechavshii za sovremennoe iskusstvo", Izvestiya December 30, 2014. 
the version signed by the president, it is therefore useful to also analyze the previous documents.

First, the document legitimated the idea of a Russian "Sonderweg". Russia was described as a unique civilization beyond the categories of "West" and "East" but uniting these two worlds. This was an indirect way of declaring Russia different from Europe. The controversial formulation of the April document that "Russia is not Europe" was abandoned in later versions, but the idea remained that Russia is based on a specific system of spiritual values, referred to as a "cultural-civilizational code". Rejecting the "liberal-Western postulate" of Universalist values, this code embraces what is considered to be traditional Russian values, i.e. national, patriotic and religious ones. These values are characterized as "conservative" and rooted in Orthodox Christianity. While restating the key role of Orthodoxy, the final version of the document mentioned the contributory role of other religions and non-Russian ethnic groups on Russian territory.

Although the major task of state cultural policy was said to preserve the identity of the Russian civilization and its specific values, an interesting aboutface took place in the presentation of Russia's relationship with the European tradition. Putin's notion that many Western countries had abandoned their roots in the Christian values of Western civilization opened the way for Russia to be portrayed as the true defender of traditional European values. Consequently, in an interview in September 2014 Medinskii called Putin a "Russian European" defending traditional European values: "Many of our emperors were authentic Europeans", he noted, "and nowadays, after an interruption of a century, a Russian European again stands as the head of Russia" (Kommersant 2014). The Putin regime had obviously discovered the potential for partnerships with authoritarian nationalist movements and parties of the "new right" on the European political scene.

Second, the document reflected an instrumentalist view of culture and a belief in its educational function. The purpose of state cultural policy is "to steadily form a national mentality", it was said, since the way to unify the nation is through strengthening the Russian value system and forming the moral orientation of the individual (Russian Government 2014). Third, the state was given an active role in the cultural sphere. The ministry, in the name of the state, was described as no longer to be "just a patron" of cultural activities but an investor. In the latter capacity the state was to become the regulator of the system of cultural institutions. Although the blunt formulations of the April working paper were removed like "not everything that presents itself as 'contemporary art' can expect to receive state support", and "a behavior that is unacceptable from the perspective of the traditional Russian system of values" 
can never be legitimatized by any references to the freedom of creativity, this approach remained. Early formulations that had indicated a censorship function like calls to cautiously scrutinize cultural products in order "not to accept the capitulation of Russian values to values alien to Russia" were omitted. Fourth, the documents reflected a managerial approach to culture. Culture was not assigned a value in itself but regarded as an investment in the development of the country in a similar way as other state investments. This was also modified in the final version.

When President Putin on 24 December 2014 signed the decree the modified formulations made it seem like a compromise document. Nevertheless, the major thoughts remained from the first working paper. This became obvious when after the Russian Crimean annexation the political atmosphere in society took a further step along the authoritarian-conservative paradigm.

The scandals around several theatre productions during spring 2015 clearly reflected that a battle was going on around culture but also that the hunt for the "internal enemy" and "fifth colon" was taking on speed. The buzzwords of the day were "offending the feelings of religious believers "and of "violating traditional Russian values" (interpreted as patriotism, orthodoxy, anti-liberalism, traditional family values and strong support for Putin as leader). These buzzwords had already been used in scandals in the arts sphere during the previous years. The spring 2015 scandal around the production of Wagner's opera "Tannhauser" at the Novosibirsk Theatre for Opera and Ballet well illustrates the intensity of the conflict, its absurdities, and the much more active and interventionist policy of the Minister of Culture who now directly intervened and fired the theatre manager (Jonson 2015b).

In this tense political atmosphere cultural productions that did not correspond to official policy came under attack. The goal of the new state policy was spelled out by Valentina Matvienko, Chairman of the Federal Council, who in 2013 stated that Russia since long was in need of new cultural standards. She was reported to have said that "during the last decades, we have witnessed a direct intervention by currents and trends which are completely alien to our unique way of life and culture" (Federation Council 2013).

Thus, reading the guidelines on state cultural policy signed by Putin in December 2014 in the context of the political debate at that time, the document comes out as a clearly authoritarian- conservative policy document. 


\section{Swings of the Pendulum and the Role of Critical Communities}

How come that this specific version of conservatism became official policy? Towards the end of the 1990s reforms in Russia had come to a standstill, corruption was rapidly growing while a rough form of capitalism had resulted in enormous social gaps. The Yeltsin regime was never able to fully carry out the economic and constitutional reforms necessary for securing a democratic development. Institutional structures and authoritarian ideas of the previous Soviet system would therefore soon reappear although this time without their previous ideological content. Society seemed in a state of fluidity where no rules of the game existed, nothing was for real and everything could be bought for money. The fluidity and cynicism of the post-communist era are illustrated in, for example, the novels Generation P by Viktor Pelevin (1999) and Around Zero (2009) by Vladislav Surkov, the grey cardinal of the Putin regime for most of the decade.

Putin, a servant of the state's secret police, reacted according to the logic of the authoritarian system every time he felt the system to be under threat. He responded to crises like the 2004 Beslan terrorist attack in the North Caucasus and the 2004 Ukrainian Orange Revolution, by centralizing the administrative system and strengthening control from above. By the end of his second mandate period (2004-2008) he had cut channels from below to influence and modernize the system.

Putin prepared the ground by his authoritarian policy and the fact that he wiped out the liberals from the public debate. His responses triggered the revival of authoritarian ideational structures. After the Beslan incident, Putin (2004) described Russia as a country under attack and at war. The Ukrainian revolution made him fear that something similar would be enacted in Russia, and he intensified his search for the 'national idea' that could unify the country and legitimatize the authoritarian Russian regime.

The deputy head of the presidential administration Vladislav Surkov formulated the concept of 'sovereign democracy' in 2005, i.e. Russia as a 'democracy' built on the Russian political traditions of authoritarian rule, a strong state, society as one entity, and a strong leader (Surkov 2006, 2007). 'Sovereignty' could here be interpreted both as the Russian state being sovereign in relation to other states but also as a political system in which the will of the people had transferred power to the leader, who saw to the interests of the state as a whole.

Moreover, Surkov reintroduced the enemy concept into the public discourse. Emphasizing the unity of the state and the nation when commenting on the Beslan attack, he spoke of the enemy from within who acts together with the external enemy in order to undermine Russia. He emphasized the 
urgency of the situation by stressing that "the enemy is at the door" and that "the front runs through every city, every street and every house" and called for "vigilance, solidarity, team spirit, and united efforts by citizens and the state" (Surkov 2004). When using the term "fifth column" he pointed to the critics of the Putin regime. ${ }^{16}$ Surkov, a skilful organizer and manipulator, was no original thinker. ${ }^{17}$ But he was innovative as he found inspiration from both Russian political philosophy and European interwar conservative theorists. Carl Schmitt seemed to have inspired Surkov's enemy concept, his use of the term sovereignty for defining the new Russian political credo and for defining Russian authoritarianism as its unique political tradition. By the time Surkov picked up by Schmitt's ideas, they were already part of a Russian radical-conservative thinking.

The Patriarchate of the Orthodox Church strongly contributed to forward a conservative paradigm. In dialogue with radical conservative thinkers the Church formulated a a coherent political-ideological platform for a Russian identity policy, a set of moral-ethic-political guidelines, a definition of Russianness built on the Orthodox belief, support of patriotism and the strong state. Its agenda of close cooperation between church and state (symphony) was a logical consequence (Bodin 2009). Thus, authoritarian-conservative thinkers found support for their ideas in the Church. The increasing influence of the Church over state and society during the first ten years of the 2ooos was reflected by the verdict of guilty in the two legal cases against organizers of the art exhibitions 'Beware! Religion' and 'Forbidden Art'. Thus, an Orthodox interpretation now dominated the interpretations of judges of the secular state of what kind of art is permitted in the public space. The patriotic-Orthodox activists who had taken the organizers to court felt the wind in their sails.

By the time the 2008 international financial crisis hit Russia, the Russian government had no clear strategic direction. There was no clear idea of how to develop the country and no meta-narrative that could show the way. ${ }^{18}$ The government seemed to oscillate between a desire for reform and a rejection of reform. In September 2009 then President Dmitrii Medvedev called for modernization and reform in his article "Go, Russia!" and criticized corruption

16 He named them "limony" (from the surname of the National Bolshevik leader Eduard Limonov) and "iabloki" (after the liberal party Iabloko under Grigorii Iavlinskii). Limony and iabloki are Russian words for lemons and apples.

Surkov created new political actors like the pro-Putin youth organization Nashi and even new political parties. Compare Pomerantsev (2014), "The Hidden Author of Putinism." The Atlantic, November 7, 2014. (Ågren 2014). 
and weak democratic and legal institutions (Russian Government website 2009). By the time of his speech to parliament in November 2009, his project seemed already buried (Bilevskaya et al. 2009). The crisis and the lack of a consistent policy response to it triggered processes in society. Medvedev's criticism had made it legitimate to discuss these issues publicly. His words had given rise to hopes and expectations that an alternative policy might be possible, and society woke up from its state of political lethargy and demanded democratic change. But his words and the events that followed also triggered the Conservatives.

\section{The Liberal Reaction}

Although liberal, leftist and anarchist opponents of the regime gathered in joint political manifestations in December 2006, such manifestations remained marginal with only a limited number of participants. After the 2007 elections no liberal parties were represented in parliament. Political organizations with democratic and liberal agendas were small and exerted no influence. Instead, it was people from the culture sector who, towards the end of the first decade of the 200os, reacted against the ongoing authoritarian development and came to play the role of critical communities forwarding democratic ideas. Within contemporary art, literature, theatre and music, democratic critical ideas took a stronghold. Visual art in particular played an important role. This can be partly explained by the expansion of galleries and art centres, mainly financed by the private sector, which contributed to making the art scene a 'free space', more independent and free than any other field of culture (Jonson 2015a). ${ }^{19}$ The community of contemporary art had reacted strongly to the trial against the 2007 "Forbidden Art" exhibition and the verdict of guilty in 2010.

Between 2009 and 2011 a critical intellectual mobilization took place. With better access to information and possibilities to travel, people from these circles could more easily draw their conclusions in favour of an alternative, democratic and liberal-oriented policy. The arts reflected a search for values other than the conservative, patriotic and religious ones of the official discourse. Individuals stood up as among the first to break the wall of silence and publicly announced that they disagreed with where society was heading (Jonson 2015a). In a way, their behaviour became examples of civic courage and an echo of Alexander Solzhenitsyn's call from the 1970s "Don't live by lie" (Zhit ne po lzhi).

19 The following builds on the study: Jonson (2015a). 
A counter-culture developed from within the subcultures of the arts (Jonson 2015a).

Social-political grassroots movements started appearing, such as the one against the building of a motorway through the Khimki natural park in the outskirts of Moscow. The Khimki movement had the support of people from the cultural sector.

Moves by Putin triggered the rapid growth of discontent and criticism. The announcement in September 2011 that he was to stand for president and Medvedev would withdraw raised a strong negative reaction. Opinion polls in the spring of 2011 had shown a long-term trend of falling support for both Putin and Medvedev, now the support fell further. By the autumn, when the campaign for the December elections to parliament started, critical voices against the regime filled the Internet.

The outcome of the parliamentary elections of early December resulted in protests against the manipulations and administrative interventions in the election process. In this respect the election did not differ much from previous elections but now there was a critical mass willing to voice its protest. The protest demonstrations of December 2011 and early 2012 that gathered around 100,00o people were a euphoric wave of hope that political change was possible. The demonstrators honestly believed that they could influence the political leadership to instigate reforms. When in December Medvedev promised smaller political reforms of the election system, this seemed to open a window of opportunity. In the March 2012 presidential election an independent liberal candidate participated for the first time - the oligarch Mikhail Prokhorov. He received 8 per cent of the votes in the country as a whole and more than 20 per cent in constituencies in Moscow. Even the art performance by Pussy Riot in the Moscow Cathedral of Christ the Saviour in February 2012 may be viewed as a reflection of the belief that people's protests can make a difference. Nevertheless, this very act was fully exploited by the conservatives in the offensive that followed.

All participants of the mass demonstrations of 2011 and 2012 were not liberal. They were a mix of Liberals, Leftists and Nationalists. Yet, at the core of their demands was the quest for democratic rights and freedoms. In that sense theirs was a liberal reaction.

\section{The Conservative Reaction}

A conservative reaction within Putin's United Russia Party was evident already when Medvedev announced the modernization campaign. 'Conservatism' was 
written into the party program in November 2009. At the party congress the same month, Boris Gryzlov, the party leader next to Putin, claimed that 'conservatism', meaning stability, development, spirituality and patriotism, fully corresponded to the modernization that Medvedev had called for (Izvestiya 2009). The call for modernization might have been a reflex by the Russian top leadership fearing the consequences of the international financial crisis in early 2009. The conservative amendment to the United Russia Party program seems to have been a counter-move by people who wanted to contain the radical thought evoked by Medvedev.

Gryzlov interpreted conservatism in terms of preserving the status quo and preventing drastic and rapid social and political change. However, as Putin's and Medvedev's support was falling and criticism against them intensifying, the regime needed a more 'dynamic' conservative approach. A militant authoritarian conservatism had already been formulated within small 'critical communities' of various shades of radical and authoritarian conservative thought. Their voices would now become listened to.

Already in the 199os Sergei Kara-Murza had formulated the ideas of a counter-offensive against the liberal paradigm of the Yeltsin regime. His book $\mathrm{Ma}$ nipulation of the Mind (Manipulatsiya soznaniem) was published in 2000 and was later reprinted and available electronically on the Internet (Kara-Murza 2005, 56-57). It was used in university courses and was widely disseminated. Kara-Murza was of the opinion that culture was of key sector as a battlefield of values. He believed that people of liberal ideas without both values and respect for authority and sacred symbols, had come to dominate the cultural sphere, and thereby also had the channels to manipulate people's minds. He blamed them for the breakdown of the Soviet Union and traced the ideas of perestroika back to the 196os and the revolt at that time by the elite of the intelligentsia of the humanities against the Soviet state. With indirect reference to the novels by the Strugatskii brothers, where progressive envoys from Planet Earth were sent to change backward planets, Kara-Murza compared the liberals with such "progressors". He saw their activities as if small but well-organized army of aliens (the intelligentsia) stood against a large, peaceful population who were entirely unprepared for such confrontation.

Referring to Antonio Gramsci, Kara-Murza claimed that the intelligentsia always has a key role in formulating and spreading an ideology and thus in setting up and breaking down the hegemony of one class over another (KaraMurza 2005, 552). ${ }^{20}$ In Russian society a split now runs, he said, along core

20 It is ironic that Kara-Murza referred to Gramsci who is usually used in emancipatory and leftist discources. 
values and norms and therefore two opposite systems of values and norms had arisen. Favouring the "Soviet project", he found liberalism and Westism to be alien to Russian thought and was against everything that he identified with the heritage of the Enlightenment of the 18th century. He thereby provided a common platform for various conservative ideas and his book was a call for a counter-offensive. It is not surprising that his name was referred to in the April 2014 document of the Ministry of Culture.

Close to the ideas of Kara-Murza were those of Alexander Prokhanov, writer and chief editor of the strongly patriotic paper Den' (The Day) of a pro-Soviet conservative blend. The paper had started in 1990 and later took the name $\mathrm{Za}$ $v$ tra (Tomorrow). When towards the end of the first decade of the 2ooos conservative voices were often heard on TV and radio, Prokhanov was frequently invited. Close to his ideas were those voiced by the communist nationalist Sergei Kurganyan and his Kurganyan Center, set up in 1990 and that gradually grew into a network of discussion clubs around the country. ${ }^{21}$ These people belonged to a pro-Soviet conservatism although without the Communist ideology.

A second direction of authoritarian conservatism was reflected in the 800page volume Russkaya doktrina (Russian Doctrine) (2005). This volume was an effort to formulate a Russian idea defined as "dynamic conservatism" and based on Orthodoxy, first of all. The editors were A.B. Kobyakov, V.V. Averyanov and Vladimir Kucherenko of the Center for Dynamic Conservatism, but the initiator of the project had been the young nationalist Egor Kholmogorov. The intention was to "consolidate a new generation of conservative intellectuals in Russia of various ideational nuances and directions" (Organisation website 2009). Emphasizing Russian "traditional values" based on the Russian Orthodox Church as the platform for restructuring Russia, the manifesto was a militant call for direct political action.

Presented in its first version in 2005, the main theses of the project were described by Kholmogorov as: a vision of the future of Russia; Russia as a unique civilization and a sacral nation based on its Orthodox belief and its grand history; the role of culture for the control of ideas; autocracy (samoderzhavie) as a system of concentrated state power; a national economy based on national interests instead of globalization; Russian demographic nationalism [in the sense of caring about the growth of the ethnic Russian population],;2 and the idea of Russia as a civilization of the North (Tyurenkov 2008).

$21 \quad$ His movement Sut vremeni was set up in 2011.

22 For its concrete expressions see the chapter by Rakhimova-Sommers in this volume. 
The church played a key role in spreading these ideas. In September 2007 Kirill organized, when still the Metropolit of Smolensk and Kaliningrad, a roundtable discussion on Russkaya doktrina at the Orthodox International Russian Popular Assembly (Kobyakov et al. 2008). He thereby moved this volume from discussions among small groups of nationalists to broad circles of the Church, and gave it his blessing. As a result it was discussed widely at universities and in the media. Critics called it "a manifesto of a new Russian conservatism" (Krug 2009) and the journal Ogonyok compared it to "the manifesto of Mussolini" (Soldatov 2007). After Kirill in 2009 became the Patriarch of the Russian Orthodox Church the ideas of the Russkaya doktrina were put forward in the anti-liberal and conservative political platform of the church. These ideas also gave inspiration to various extreme political groups. Among them was Narodnyi sobor, whose leader Oleg Kassin had been the left hand of the Russian fascist leader Barkashov of the Russian National Unity up until 2001 when the two split.

A third direction of militant conservatism was presented by Alexander Dugin's ideas of "Eurasianism". His lofty theories predicted Russia to be the future great empire of the continental Eurasian landmass in permanent conflict with the Atlantic powers led by the USA (Dugin 200o). His imperial version of state nationalism also had much to offer as an alternative to a Russian ethnic-based nationalism.

Dugin was the creator of the movements Euraziya (2000), the Eurasian Movement (2003) and the Eurasian Youth Union (2005). After 2005 his political and academic career took off: he became an adviser to the Duma, cooperated with ministers and the presidential administration, and frequently published comments in the media. In 2008 he was invited to create the Institute of Conservative Studies at the Department of Sociology of Moscow State University (MGU), where he became a Professor and set up his educational programme (Dugin website). Becoming the head of the section of sociology of international relations at the department in 2010 (until June 2014), his chances to spread his message increased tremendously (Dugin website).

However, Dugin may have been more important as a translator and introducer in the early 1990s of European interwar theorists and philosophers of authoritarian conservative thought, i.e. European theorists of the so-called conservative revolution. Among them are Julius Evola, Ernst Jünger, Oswald Spengler and Carl Schmitt. As the ideological inspirator of the conservative Underground of the early 1990 s like the National Bolshevik Party, ${ }^{23}$ Dugin socialized with people from cultural circles and spread these ideas. The intensive

23 For more about this formation see the chapter by Rogatchevski in this volume. 
nihilist anarchism of Evola made a strong impact among artists and punk musicians of St Petersburg participating in the activities of the National Bolshevik Party during those years. The National Bolsheviks continued a conservative revolutionary heritage but in a mainly anarchist form. In 1998 Dugin broke away from Limonov and from the National Bolsheviks.

Carl Schmitt's ideas resonated in Russia in large part owing to Dugin's courses at the MGU on the political philosophy of Schmitt at the MGU, where numerous academic essays on Schmitt were produced. The cold realistic-pragmatic concepts and analyses by Schmitt as a critic of the constitutional democratic but weak Weimar republic of Germany in the 1920s provided the analytical tools for an analysis of Russian post-communist society and for formulating a strategy for a Russian conservative revolution. Over the period 2000-2014, 10 of Schmitt's works were published in Russian. These ideas were linked to those of the contemporary European "new right". Alain de Benoist published his book Carl Schmitt Today (Karl Schmitt segodnya) in Russian with a special introduction, "Carl Schmitt for Russia" (de Benua and Shmitt 2014).

In his essay from 1991 "Carl Schmitt: Five Lessons for Russia" Dugin emphasized the idea of the nation as a unique entity based on its internal spiritual and volitional laws of development. The state was looked upon as the representative of the will of the people and the popular will as a unified entity. In line with Schmitt he found everything 'political' to be related to the state and state interests were regarded to be supreme and to penetrate all issues in society. Like Schmitt Dugin was against a 'universalism' with regard to the idea that all individuals have equal rights and value and that mankind has common interests. The cornerstone in Schmitt's thinking - the emphasis on "sovereignty" in the sense of the state's interests being supreme both within the country and internationally and his sharp distinction between the enemy (both internal and external) and the friend of the state - are emphasized by Dugin (1992). Thus, from here Surkov seems to have found inspiration for his formulations of "sovereign democracy" and "the enemy from within". The ideational heritage from radical conservative thought of the European 1920 s can be found today among the United Russia Party and the Duma as exemplified by Evgenii Fedorov, a member of the United Russia Party and a Duma delegate, who in the early 2010 s created the so-called Russian Liberation Movement (NOD). Fedorov represents a fourth and radical conservative direction, which can best be described as a kind of pragmatic fascism, yet without the lofty theories of Dugin's Eurasianism.

Thus, although there was a multitude of various conservative ideas and directions in Russia in the 200os, they all shared ideas of anti-liberalism, 'antiWestism', patriotism, belief in the mighty state, the strong leader, the authori- 
tarian and hierarchical society, moral restoration, the central role of religion, and the Sonderweg as the national path based on the uniqueness of the nation. And they all were convinced that time was now on the side of the Conservatives.

Militant conservative ideas were institutionalized during the late $2000 \mathrm{~s}$ when think-tanks, discussion clubs and analytical institutes were created out of previous less formal clubs and centres. These people stood by Putin when in the spring of 2011 opinion surveys revealed a drastic and long-term fall in support for him, they supported him in the creation of the conservative pro-Putin All-Russian People's Front in May 2011. They stood by him when, in his most vulnerable moment after the mass protests in December 2011, he needed manifestations of support. They organized pro-Putin mass meetings in Moscow that helped create the image of his grand comeback. ${ }^{24}$

In spite of all differences these groups of militant conservatism, they have a lot in common. In an effort to create a common platform for discussions between Conservatives of various brands and state representatives the Izborskii club of experts was created in September 2012. ${ }^{25}$ The intention behind the club was to create an alternative to the Valdai Club, which they found too "liberal".

Thus, already during the 199os conservative ideas of a revolutionary kind were formulated by small communities of intellectuals critical of the Yeltsin regime. These communities consolidated during the 2000 s and their ideas spread. They did not manage to build or link to social movements. Their main contribution was instead the intellectual work of formulating a more outspoken nationalist and conservative ideology, defining concepts and inspiring

24 The pro-Putin mass-rallies were organized by the Anti-Orange Committee (Anti-oranzhevoi komitet) which was led by a coalition of various conservative forces including Sergei Kurginyan, Aleksander Prokhanov, Aleksander Dugin, Vadim Kvyatkovskii head of the patriotic movement Georgevtsii, Vyacheslav Sivko head of the fund in name of General Kocheshkov in support of heroes of the Soviet Union and Russia, Nikolai Starikov head of the movement TradeUnion of Russian Citizens, and the journalists Mikhail Leontiev, Maksim Shevchenko and Marina Yudenich. Their website <http://anti-orange.ru > no longer exists. However, their internal meeting of 22 February 2012 was filmed and can be found at $<$ https://www.youtube.com/watch?time_continue=2074\&v=LIjgCMPYr2Y> .

25 Created in September 2012 the Izborskii club had among its permanent members chief editor of Zavtra Alexander Prokhanov, the head of the Institute of Dynamic Conservatism V.V. Averjanov, the presidential adviser and co-founder of the Rodina party Sergei Glaziev, the leader of the Eurasian movement Alexander Dugin, the TV journalist Mikhail Leontiev, the head of the Russian National Liberation Movement and Duma delegate for United Russia Andrei Fursov, and Arkhimandrit Tikhon (Shevkunov) the head of the Sretenskii monastery. Postoyannye chleny Izborskogo kluba. Most interesting is that in this first conference to discuss the ideological platform of the pro-Putin All-Russian People's Front also participated the new minister of culture Vladimir Medinskii. 
visionary and strategic thinking. They gave food for thought to the Putin regime and offered it useful concepts. They also contributed practical, direct and organizational work in support for him at a crucial moment.

When Putin returned as president in May 2012, his political agenda was influenced by these new allies. With these ideas partly reminiscent of ideas that had dominated Europe in the 1920s and 1930s, Medinskii was correct when he wrote Putin into European history as a European Russian. Putin followed the dark authoritarian tradition of European ideas.

\section{Political Change and the Role of Critical Communities}

Putin's agenda of 2012 was not status-quo-oriented. Instead it was offensive in the sense that it was intended for inserting conservative values and marginalizing remnants of liberal thought. It was formed under the impact of revolutionary conservative ideas. Against this background, culture became a key sector for implementing change.

In discussing the factors behind Putin's conservative turn, this chapter focussed on the role played by small, critical communities for formulating new ideas and concepts. Both the conservative and liberal intellectual communities were reactions to the development of the post-Soviet political system. None of them were able to create social movements. The conservative-revolutionary communities, although unable to build social movements, were successful in gradually consolidating their position. In the end they were the most successful as their ideas were adopted by the Putin regime.

Putin acted according to the logic and mechanisms of the authoritarian Soviet system, which institutional and ideational structures were never fully deconstructed after 1991. Yet, his choice of the brand of authoritarian conservatism with its ideational links to a interwar European political heritage and to the contemporary European 'new right', can only be explained by the influence from ideas of the radical conservative communities. Their ideas were instrumental to the regime.

The protest movement of 2011-2012, which emanated from critical communities, first of all from within the cultural sphere, brought a large emancipatory potential based on values of civic rights, the rule of law, and the freedom and rights of the individual. As these ideas were transferred into embryonic socialpolitical movements, they were articulated as liberal, liberal-conservative, leftist, anarchist, and nationalist political views. Without a common political agenda beyond the demands for free elections and the release of political prisoners, these mass protests became first of all a manifestation of a value system 
in conflict with that of the Putin regime. It was neither a political opposition nor a proper social movement.

After the protest movement was repressed in 2012-2013, liberal critical communities within the cultural sphere survived, although they were diminished in size as conformism spread in society. A critical eye and an interest in social issues that had been an important trend in Russian theatre, film and art during the early 2010 s remained. However, now a more wary look at the possible consequences was needed.

The Russian annexation of the Crimea in the spring of 2014 further consolidated the official conservative agenda and also resulted in a polarization of society that split families and friends. Support for Putin was secured by what Russian sociologist Lev Gudkov (2014) called "a conservative consolidation around power". Public opinion polls showed an increase in support for Putin to more than 80 per cent. That much support, Gudkov explained, is possible only when there is a feeling that the very existence and survival of the nation and the state are under threat. This feeling had spread as a result of the daily cannonade of state propaganda hammering in the message through $\mathrm{TV}$, the media on which most people rely for their information and news reporting. The atmosphere was like an emergency situation in which, according to authoritarian conservative thought, the role of the leader must increase and his rights extended to decisions that may violate the norms of the regular situation. $\mathrm{Pu}-$ tin's handling of the crisis in Ukraine in 2014 and 2015 seemed to follow the prescriptions of the radical conservative communities of what need to be done in a situation that they defined as an existential threat to Russia, a question of "life or death".

Against this background the 2014 proposal of state cultural policy seemed to be a logical part of the new conservative paradigm. This does not mean that the leaders of these conservative communities were offered good positions in the new government. Yet, they became part of the political establishment and their ideas were now à la mode.

Looking back it is obvious that the conservative intellectual communities were more successful than the liberal ones. None of them were able to create sustainable social movements, but the ideas of the conservative communities were picked up by the regime at a movement of desperate search of new ideas to maintain power and control over society. Some of them are now adding to a development that takes Russian policy further and further into a conservative extreme.

However, those responsible for the new state policy had probably not counted on the continued resistance from people of the cultural sphere. Moreover, they seem to have ignored the fact that cultural life in Russia is partly privately 
financed and thus presently is beyond the capacity of the ministry to control. To implement a new state cultural policy according to an agenda of authoritarian conservatism may therefore turn out to be more difficult than expected in spite of the latest Conservative swing of the pendulum.

\section{References}

Ågren, Mattias. 2014. "Phantoms of a Future Past. A Study of Contemporary Russian AntiUtopian Novels." PhD thesis in Slavic Languages. Stockholm University.

Bazhanov, Leonid. 2014. "Minkul'tury likvidirovalo otdel, otvechavshii za sovremennoe iskusstvo." Izvestiya 30 December, 2014. Accessed February 3, 2018. < http://izvestia. $\mathrm{ru} /$ news $/ 581421>$.

Bilevskaya, E., Samarina, A., M. Sergeev, A Blinov, and v. Soloviov. 2009. "Prezidentskii instruktazh dlya elit vsekh urovnei." Nezavisimaya gazeta November 13 2009. Accessed February 3, 2018. <http://www.ng.ru/politics/2009-11-13/1_modernizaciya. html>.

Bodin, Per-Arne. 2009. Language, Canonization and Holy Foolishness: Studies in Postsoviet Russian Culture and the Orthodox Tradition. Stockholm: Stockholm University.

Borisova, Darya. 2012. "My vam zakazhem: 'Minkul't nameren opredelyat' tematiku finansiruemykh fil'mov." Nezavisimaya Gazeta, September 18, 2012. Accessed February 2, 2018. <http://www.ng.ru/cinematograph/2012-09-18/10o_medinskiy.html>.

Centre for Dynamic Conservatism. 2009. "Ob Institute dinamicheskogo konservatizma." Accessed February 3, 2018. <http://www.dynacon.ru/opr/idk.php>.

Colta. 2014. "Akademiki RAN raskritikovali 'Osnovy gosudarstvennoi kul'turnoi politiki.” Colta, April 16, 2014. Accessed February 4, 2018. < http://izvestia.ru/news/569o16>. de Benua, Alen and Karl Shmitt. 2014. Segodnya. Moskva: ION.

Dugin, Aleksander Gelevich. 1992/2001. "Karl Shmitt: 5 urokov dlya Rossii". Accessed 7 March 2018. <http://my.arcto.ru/public/rv/13.shtml>. (Originally published in the journal Nash sovremennik in 1992).

Dugin, Aleksander Gelevich. 2000. Osnovy geopolitiki. Geopoliticheskoe budushchee Rossii. Moskva: Arktogeya.

Dugin, Aleksandr Gelevich, "Biografiya i osnovnye trudy", Accessed 7 March 2018 $<$ http://dugin.ru/biography>.

Dugin, Alexander Gelevich. n.d. Personal website. $<$ http://dugin.ru/biography $>$.

dynacon.ru. n.d. “LITSA PRоектA.” Accessed February 4, 2018. dynacon.ru/lpr/izborsk. php.

Federation Council, 2014, "Spiker SF: Obshchestvennyi dialog v ramkakh Goda kul'tury pomozhet ukrepit' edinoe dukhovnoe prostranstvo". 9 October 2013, Accessed 7 March 2017, <http://www.council.gov.ru/events/news/35789/>. 
Gashkov, Igor. 2014. "RPTs khochet vospityvat' shkol'nikov." Nezavisimaya gazeta (website), September 4, 2014. Accessed February 1, 2018. <http://www.ng.ru/faith/2014og-04/1_rpc.html>.

Government of the Russian Federation website. 2013. Zasedanie Soveta po kulture $i$ iskusstvu, October, 2013. Accessed January 30, 2018. <http://news.kremlin.ru/tran scripts/19353>.

Government of the Russian Federation. 2013. Vneseny izmeneniya $v$ zakon o zashchite detei ot informatsii, prichinyayushchei vred ikh zdorovyu i razvitiyu. Moscow: Federal Government Website. June 30, 2013. Accessed February 1, 2018. <http://kremlin.ru/ acts $/ 18423>$.

Government of the Russian Federation. 2014. Osnovy gosudarstvennoi kul'turnoi politiki. Utverzhdeny ukazom prezidenta RF. Moscow: Federal Government Website. December 24, 2014. Accessed February 3, 2018. <http://kremlin.ru/acts/18423>.

Government of the Russian Federation. 2014. Osnovy gosudarstvennoi kul'turnoi politiki. Utverzhdeny ukazom prezidenta RF. Moscow: Federal Government Website. December 24, 2014. Accessed February 3, 2018. <http://kremlin.ru/acts/18423>.

Grani. 2012. "V administratsii prezidenta sozdano 'patrioticheskoe' upravlenie" October 20, 2012. Accessed 7 March 2018. <https://graniru.org/Politics/Russia/President/m. 207616.html>.

Grani. 2014a. "V Gosdume podgotovili zakonoproekty o patrioticheskom vospitanii v shkolakh." Grani, August 19, 2014. Accessed 2 February, 2018. <http://grani.ru/Poli tics/Russia/Parliament/Duma/m.232186.html>.

Grani. 2014b. "RPTs: Osnovy pravoslavnoi kul'tury nado prepodovat' so 2-go po 10-I klass." Grani September 8, 2014. Accessed February 2, 2018. < http://grani.ru/society/ Religion/m.232777.html>.

Gudkov, Lev. 2014. "Putinskii retsidiv totalitarizma”, Pro et Contra (May- August).

Iablokov, Aleksei. 2013. "V 2014 godu gosudarstvo vserioz vozmetsya za kul'turu." Vedomosti (online edition, October 11, 2013. Accessed February 3, 2018. <http://www. vedomosti.ru/lifestyle/news/17373481/v-2014-godu-gosudarstvo-vserez-vozmetsyaza-kulturu?full\#cut>.

Izvestiya. 2009. "Sokhranit' i priumnozhit': konzervatizm i modernizatsiya." Izvestiya (online) December 1, 2009. Accessed February 3, 2018. < https://iz.ru/news/355987>.

Izvestiya. 2014. "Minkul'tury izlozhilo 'Osnovy gosudarstvennoi kul'turnoi politiki." Izvestia (online edition), April 10, 2014. Accessed February 4, 2018. < http://izvestia.ru/ news/569016>.

Jonson, Lena. 2015a. Art and Protest in Putin's Russia. London and New York: Routledge. Jonson, Lena. 2015b. "Russia: Cultural Freedom Under Threat." Artsfreedom, May 11, 2015. <https://freemuse.org/news/russia-cultural-freedom-under-threat-2/>. Accessed February 28, 2018.

Jonson, Lena and Erofeev, Andrei, eds. 2018. Russia - Art Resistance and the Conservative-Authoritarian Zeitgeist. London \& New York. 
Kara-Murza, Sergei. 2005. Manipulatsiya soznaniem. Moskva: MediaKniga. Accessed February 3, 2018. <http://bookz.ru/authors/sergei-kara-murza/karamurza/1-kara murza.html>.

Karev, Igor and Aleksei Krizhevskii. 2013. "Permyu menshe. Samye rezonansnye kul'turnye sobytiya 2013 goda." Gazeta, 27 December 2013. Accessed February 28, 2018. <https:/www.gazeta.ru/culture/2013/12/26/a_5821217.shtml >.

Kleiman, Naum. 2014." 'Nuzhen li goszakaz v kino? Ostrannenyi ot dolzhnosti direktor Muzeya Kino Naum Kleiman - o tom, kak sozdat' natsional'nyi kinematograf, i o tupom avtoritarnom upravlenii kul'turoi." Interviewed by Yuliya Ryzhenko, Colta, June 10, 2014. Accessed February 2, 2018. <http://www.colta.ru/articles/specials/ $3507>$.

Kobyakov, A.B., v.V. Averyanov, and Vladimir Kucherenko, eds. 2008. Russkaya doktrina. Moskva: Yauza-Press. Accessed Februrary 3, 2018. <http://bdn-steiner.ru/forums/ index.php/topic,445.o.html>.

Krug, Pavel. 2009. "Komu lyazhet na stol 'Russkaya doktrina'?" Nezavisimaya gazeta, September 5, 2009. Accessed February 3, 2018. Reposted on <http://www.rusdoctri na.ru/page95798.html>.

Lapina, Alina. 2014. "Khudozhnikam budut vydavat' den'gi za talant i krasivye raboty." The Art News Paper Russia, no. 29 December/January. Accessed February 3, 2018. <http://www.theartnewspaper.ru/posts/1055/>.

Lenta. 2013. "Putin vystupil za unifikatsiyu uchebnikov istorii." Lenta February 19, 2013. Accessed 7 March 2018. <https://lenta.ru/news/2013/02/19/history/>.

Mamontov, Arkadii. 2012. "Provokatory I." Broadcast April 24, 2012 on TVI. Accessed February 1, 2018. Video, 1:09:47. Accessed February 28, 2018. <https://www.youtube. $\mathrm{com} /$ watch?v=gJy631vsou4\&feature $=$ youtu.be $>$.

Mamontov, Arkadii. 2012. "Provokatory II." Broadcast September 11, 2012 on TVI. Video, 1:20:15. Accessed February 28, 2018. <https://www.youtube.com/watch?v=T8uRG koqRJw $>$.

Mamontov, Arkadii. 2012. "Provokatory III." Broadcast 16 October 2012 on TVI. Video, 1.15.o9. Accessed 28 February 2018. <https://www.youtube.com/watch?v=vwk-v5jwRk $>$.

Medinskii, Vladimir. 2013."Ministr kultury RF Vladimir Medinskii: "Bez ideologii chelovek stanovitsya zhivotnym!" (Interview) Kul'tura, September 4, 2013. Accessed February 28, 2018. Reposted <http://www.orthedu.ru/news/7885-ministr-kultury-rfvladimir-medinskij-bez-ideologii-chelovek-stanovitsya-zhivotnym.html>.

Medinskii, Vladimir. 2014. "Zadacha kul'turnoi politiki - vyrastit' pokolenie pobeditelei."' Interviewed in Kommersant (online edition), September 18, 2014. Accessed February 4, 2018. <http://www.kommersant.ru/doc/2569559>.

Medvedev, Dmitrii. 2009. “Go, Russia!” Moscow: Federal Government Website. September 10, 2009. Accessed February 3, 2018. <http://eng.kremlin.ru/news/298>. 
Mel'nikov, Andrei, 2012, "Nochnoi koshmar ot Arkadiya Mamontova", Nezavisimaya gazeta, 13 September, <http://www.ng.ru/politics/2012-09-13/2_mamontov.html>. Accessed February 28, 2018.

Mel'nikov, Andrei and Orlova, Lidiya, 2013, "Pomni o 'dvushchechke”, Nezavisimaya gazeta, 19 June, <http://www.ng.ru/ng_religii/2013-06-19/1_feelings.html>. Accessed February 28, 2018.

Ministerstvo kul'tury Rossiiskoi Federatsii. 2013. "Gosudarstvennyi doklad o sostoyanii kul'tury v Rossiiskoi Federatsii v 2013 godu.” Russian Government (website pdf). n.d. Accessed February 3, 2018. <http://mkrf.ru/upload/mkrf/mkdocs2014/doklad_ block.pdf>.

Morozov, Aleksandr. 2012. "Medinskii v interere. Pozitivnost' fashizma." Open Space, 23 May, 2012. Accessed February 1, 2018. <http://os.colta.ru/society/russia/details/ $37261 />$.

New Times, 2012, "Kto ya takoi, chtoby Putina obsuzhdat'?", 26 November. Accessed February 28, 2018, <http://www.newtimes.ru/articles/detail/60282>.

Nezavisimaya gazeta. 2013. "Minkul't otorvalsya ot zhizni." September 18, 2014. Nezavisimaya gazeta (online edition). Accessed February 3, 2018. <http://www.ng.ru/edi torial/2014-09-18/2_red.html>.

Nezavisimaya gazeta. 2013. "Prezident vzyal kurs na konservatizm." Nezavisimaya gazeta (website), 30 December 30, 2013. Accessed February 1, 2018. <http://www.ng.ru/ politics/2013-12-30/3_conservative.html>.

Nezavisimaya gazeta. 2014. "Minkul'tury vyiavlyaet 'novye tendentsii gospolitiki v sfere sovremennogo iskusstva." Nezavisimaya gazeta (online edition), December 11, 2014. Accessed February 3, 2018. <http://www.ng.ru/columnist/2014-12-11/8_minkult. html >.

Nicodemus, Katja. 2014. "Skandal in Moskau. Das russische Filmmuseum wird systematisch zerstört!" Zeit Online, November 15, 2014. Accessed February 2, 2018. < http:// www.zeit.de/2014/45/filmmuseum-moskau-larissa-solonicina $>$.

NTV. 2012. "Anatomiya Protesta I." Broadcast March 15, 2012. Accessed 1 February 1, 2018. Video, oo:36:30. <http://www.ntv.ru/video/peredacha/296996/>.

NTV. 2012. "Anatomiya Protesta II." Broadcast October 5, 2012. Accessed February 1, 2018. Video, oo:48:23. <http://www.ntv.ru/video/354142/>.

Pelevin, Viktor .1999. Pokolenie "P." Moskva: Vagrius.

Pomerantsev, Peter. 2014. "The Hidden Author of Putinism." The Atlantic (online newspaper), November 7, 2014. Accessed February 3, 2018. <http://www.theatlantic.com/ international/archive/2014/11/hidden-author-putinism-russia-vladislav-surkov/ $382489 /$ ?singlle_page=true $>$.

Putin, Vladimir. 2004. "Obrashchenie Prezidenta Rossii Vladimira Putina 4 sentyabrya 2004 goda." Accessed February 28, 2018. <http://www.kremlin.ru/events/president/ transcripts/22589>. 
RF Federal'nyi zakon ot 20 iyulya 2012g. No 121-F3. O vnesenii izmenenii v otdel'nye zakonodatel'nye akty RF v chasti regulirovaniya deyatel'nosti nekommercheskikh organizatsii, vypolnyayushchikh funktsii inostrannogo agenta. Accessed February 28, 2018. <http://www.kremlin.ru/acts/bank/35748>.

RF Federal'nyi zakon ot 8 iyunya 2012g, N 65-F3. O vnesenii izmenenii $v$ Kodeks $\mathrm{RF}$ ob administrativnykh pravonarushcheniyakh i Federal'nyi zakon "O sobraniyakh, mitingakh i demonstratsiyakh, shestviyakh i piketirovaniyakh. Accessed February 28, 2018. http://www.kremlin.ru/acts/bank/35458>.

RF Federal'nyi zakon ot 28 iyulya 2012g. No 141-F3. O vnesenii izmeneniya v Ugolovnyi kodeks RF I otdel'nye zakonodatel'nye akty RF. (Kleveta). Accessed February 28, 2018. <http://ivo.garant.ru/\#/document/70207752:0>.

RF Federal'nyi zakon ot 29 iyunya 2013g. N136-F3. O vneseni iizmenenii $v$ statyu 148 ugolovnogo kodeksa RF i otdel'nye zakonodatel'nye akty $R F v$ tselyakh protivodeistviya oskorbleniyu religioznykh ubezhdenii i chuvstv grazhdan. Accessed February 28, 2018. $<$ http://www.consultant.ru/cons/cgi/online.cgi?req=doc\&base $=$ LAw $\& n=148270 \& f l$ $\mathrm{d}=134 \& \mathrm{dst}=1000000001,0 \& \mathrm{rnd}=0.750571268871135^{\# 0006579163232337648>}$.

Rossiiskaya gazeta. 2013. "Vystuplenie Vladimira Putina na zasedanii kluba "Valdai." September 19, 2013. Accessed January 30, 2018. <http://www.rg.ru/2013/og/19/stenogramma-site.html>.

Rossiiskaya gazeta. 2014. "Osnovy gosudarstvennoi kul'turnoi politiki." Rossiiskaya gazeta (online edition), May 16, 2014. Accessed February 3, 2014. <http://www.rg. $\mathrm{ru} / 2014 / 05 / 15 /$ osnovi-dok.html >.

Soldatov, Aleksander. 2007. "Atomnoe pravoslavie." Ogonyok, no. 37 (September). Accessed February 3, 2018. <http://www.rusdoctrina.ru/page95795.html>

Stepanov, Anatolii. 2013. "Valdaiskaya rech' Putina." Russkaya narodnaya liniya. Informatsionno-analiticheskaya sluzhba. 20 September 2013. <http://ruskline.ru/news_ rl/2013/og/20/valdajskaya_rech_putina $>$.

Surkov, Vladislav. 2006. "Natsiionalizatsya budushchego." In Teksty 97 - o7. Moskva: Izdatelstvo "Evropa."

Surkov, Vladislav. 2007. "Russkaya politicheskaya kul'tura. Vzglyad iz utopii (lecture at the Russian Academy of Sciences June 8, 2007)." In Teksty 97 - 07. Moskva: Izdatelstvo "Evropa."

Surkov, Vladislav. 2009. Okolonolya [gangstafiction]. Moskva: Russkii Pioner. Spetsialnyi vypusk.

Surkov, Vladislav. 2004. "Zamestitel' glavy administratsii Prezidenta RF Vladislav Surkov: Putin ukreplyaet gosudarstvo, a ne sebya." Komsomol'skaya Pravda, September 28, 2004. Accessed February 3, 2018. < http://www.kp.ru/daily/23370/ $32473>$.

Tyurenkov, Mikhail. 2008. "Russkaya doktrina 'Non Stop'. Pravaya.ru. Accessed February 3, 2018. <http://pravaya.ru/idea/169/5895>. 